\title{
Potensi Susu Kedelai Asam (Soygurt) Kaya Bioaktif Peptida Sebagai Antimikroba
}

\section{Potential of Acid Soymilk (Soygurt) of Rich Peptide Bioactive as Antimicrobial}

\section{Dwi Eva Nirmagustina dan Chandra Utami Wirawati}

Program Studi Teknologi Pangan, Politeknik Negeri Lampung (POLINELA)

Jln. Soekarno-Hatta No.10 Rajabasa Bandar Lampung 35144

E-mail: dwievan_polinela@yahoo.co.id

\begin{abstract}
The research objective was to get the starter type and the fermentation time to produce soygurt that have a high peptide bioactive that functions as an antimicrobial. The study was conducted in a complete randomized block design with two replicates. The first factor is the starter types, which consists of 3 levels, 2 market starter (cimory and king yogurt) and 1 mixed starter. The second factor is the fermentation times, which consists of 3 levels, 9 hours, 12 hours, and 15 hours. The data obtained were analyzed by analysis of variance to get various error estimators and tests of significance by Duncan's test further to determine whether there is a difference between treatments. Two market starter (cimory and king yogurt) and 1 mixed starter did not produce peptide bioactive compounds. It is suspected microbes contained in the market starter cimory (S.thermophilus and L.delbrueckii ssp . Bulgaricus ), the market starter king yogurt (L.bulgaricus) and mixed starter (S.thermophilus and L.bulgaricus) did not produce peptide bioactive compounds. The inhibition effect of the test bacteria (E. coli and S. aureus) occurs due to the production of lactic acid and hydrogen peroxide during the fermentation process. The greatest inhibition shown by soygurt of the market starter cimory with a reduced number of cells in both types of test bacteria (E. coli and S. aureus) at 6 and $5 \log$ cycles. Mixed starter has the lowest $\mathrm{pH}$ and the highest total acid than the marker starter cimory and king yoghurt. The starter types and the fermentation times were no significant effect on total dissolved solids of soygurt. The levels protein of soygurt, respectively $1.38 \%, 1.48 \%$, and 1.68 (cimory, king yogurt, and mixed starter), while the fat content of soygurt $1.04 \%, 1.28 \%$, and $1.58 \%$ (cimory, mixed starter, king yoghurt)
\end{abstract}

Keyword: soygurt, peptide bioactive, antimicrobe

Diterima 19-03 2014, disetujui: 27-06-2014

\section{PENDAHULUAN}

Peptida merupakan salah satu sumber ingredient pangan fungsional yang sangat penting. Pada dasarnya tubuh memiliki peptida endogen yang sebagian besar berfungsi sebagai hormon dan neurotransmiter yang berperan penting dalam proses fisiologis. Namun dalam beberapa dekade terakhir, para peneliti menemukan bahwa bioaktif peptida dapat juga diperoleh dari protein yang 

dikonsumsi. Peptida tersebut dapat berdiri sendiri atau masih terikat pada protein asalnya. Telah diketahui bahwa selama hidrolisis dalam saluran pencernaan atau selama pengolahan pangan (fermentasi), peptida tersebut dapat dilepaskan dari protein, dan kemudian di dalam tubuh dapat bekerja sebagai senyawa regulator yang aktifitasnya menyerupai hormon. Peptida juga memiliki aktifitas biologis lain seperti antihipertensi, antioksidatif, antitrombotik, hiperkolestrolemik (sistem kardiovaskuler), "opioid" agonistik dan antagonistic (sistem saraf), anti selera makan, antimikroba (sistem gastrointestinal), imodulator, sitomudolator (sistem imune) (Korhonen dan Pihlanto, 2006).

Susu kedelai merupakan sumber protein yang baik. Susu kedelai dapat difermentasi menghasilkan susu kedelai asam (soygurt). Kondisi fermentasi akan memberikan pengaruh terhadap terbentuknya bioaktif peptida. Dalam produk olahan hasil fermentasi, bioaktif peptida yang terbentuk tergantung pada jenis bakteri yang terdapat dalam kultur starter dan derajat hidrolisis (waktu fermentasi) yang terjadi. Proses proteolisis yang cukup diperlukan untuk memfasilitasi pelepasan bioaktif peptida dari protein, namun proses proteolisis yang berlebihan justru akan menurunkan aktifitasnya.

Soygurt adalah produk pangan hasil fermentasi susu kedelai. Susu kedelai mengandung offflavour yang kurang disukai yang sering disebut langu kedelai (beany flavour). Fermentasi merupakan salah satu upaya yang dilakukan dan telah terbukti dapat meningkatkan nilai gizi dan memperbaiki akseptabilitas susu kedelai (Karleskind, 1991). Selain itu soygurt juga mempunyai beberapa manfaat yang ditimbulkan oleh proses fermentasi bakteri asam laktat, yaitu menyeimbangkan sistem pencernaan, menurunkan kadar kolesterol, mencegah kanker, dan mengatasi infeksi jamur dan bakteri (Hendriani, 2009).

Bakteri asam laktat dalam soygurt akan menghasilkan suatu senyawa yang akan melawan infeksi mikroba patogen dalam tubuh, seperti infeksi karena jamur Candida albicans dan bakteri Helicobacter pylori. Senyawa ini adalah senyawa dengan bobot molekul rendah baik berupa protein atau peptida pendek yang memiliki aktivitas menghambat atau membunuh mikroba (antimikroba) (Marshal, 2003).

Antimikroba dari senyawa peptida merupakan molekul kofaktor dalam sistem pertahanan tubuh dan sistem imunitas terhadap infeksi (Yeaman dan Yount, 2005). Penggunaan antimikroba dari senyawa peptida dalam bidang pengobatan sangat potensial, karena AMP (Antimicrobial Peptide) dapat merekonstruksi sel target dan memiliki kemampuan antimikroba yang lebih kuat dibanding antibiotik biasa. Menurut Yeaman et al., 2005, senyawa ini dapat meregulasi sel target untuk memodifikasi struktur di luar selnya agar lebih sensitif terhadap antibiotik, 2) mengatasi resistensi, 3) bekerja secara non-kompetitif dengan antibiotik biasa.

Proses fermentasi susu kedelai menjadi soygurt sangat dipengaruhi oleh jenis starter yang digunakan dan waktu fermentasi berlangsung. Jenis starter yang biasa digunakan terutama dari kelompok bakteri asam laktat yaitu Streptococcus salivarus subsp. thermophilus dan Lactobacillus delbrueckii subsp. bulgaricus, serta Lactobacillus acidophilus, Lactobacillus casei dan Bifidobacterium sebagai bakteri probiotik (Shah, 1999).

Proses fermentasi susu kedelai menjadi soygurt memerlukan waktu yang lebih lama dibandingkan dengan proses fermentasi susu sapi menjadi yoghurt. Hal ini disebabkan proses pemecahan karbohidrat susu kedelai (oligosakarida) oleh bakteri membutuhkan waktu yang lebih lama karena strukturnya yang kompleks (Sari, 2007). Kombinasi antara jenis starter dan waktu fermentasi susu kedelai menjadi soygurt akan berpengaruh terhadap proses pembentukan komponen bioaktif peptida soygurt. 
Tujuan penelitian secara umum adalah menghasilkan soygurt yang memiliki komponen bioaktif peptida yang tinggi yang berfungsi sebagai antikmikrobadan mendapatkan jenis starter dan waktu fermentasi yang menghasilkan soygurt yang mempunyai komponen bioaktif peptida yang tinggi yang berfungsi sebagai antimikroba.

\section{METODE}

Bahan yang digunakan adalah kedelai, susu skim, glukosa, 2 jenis starter pasar ((cimory dan king yoghurt) dan starter campuran (Lactobacillus bulgaricus : Streptococcus thermopilus), bakteri uji Escherichia coli (ATCC 25922) dan Staphylococcus aureus (ATCC 939), dan bahan kimia untuk uji sifat kimia dan sifat fungsional. Alat yang digunakan adalah baskom, panci, kompor, blender, saringan, dan alat untuk uji sifat fisik, sifat kimia, dan sifat fungsional.

Penelitian disusun secara faktorial dalam rancangan acak kelompok (RAKL) dengan 2 ulangan. Faktor pertama (A) adalah jenis starter, yang terdiri dari 3 taraf, yaitu 2 starter pasar (cimory dan king yoghurt), 1 starter campuran (Lactobacillus bulgaricus : Streptococcus thermopilus). Faktor kedua (B) adalah waktu fermentasi, yang terdiri dari 3 taraf, yaitu 9 jam, 12 jam, 15 jam. Penelitian yang dilakukan terdiri dari 2 tahap, yaitu (1) pembuatan susu kedelai dan (2) pembuatan soygurt

\section{Pembuatan Susu Kedelai}

Susu kedelai yang digunakan untuk membuat soygurt adalah susu kedelai yang dihasilkan dari proses basah. Kedelai disortasi, direndam selama 3 jam, dan diblansing \pm 10 menit. Kemudian kedelai digiling dengan penambahan air panas sebanyak 8 bagian. Bubur kedelai disaring dengan kain saring. Selanjutnya susu kedelai dipanaskan sampai mendidih. Susu kedelai yang dihasilkan digunakan untuk membuat soygurt. Diagram alir pembuatan susu kedelai dapat dilihat pada Gambar 1.

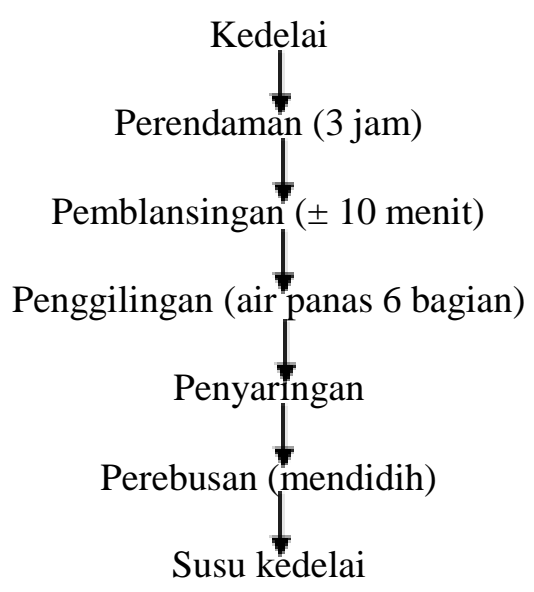

Gambar 1. Diagram alir pembuatan susu kedelai

\section{Pembuatan Soygurt}

Soygurt dibuat dengan cara mencampur susu kedelai dengan susu skim sebanyak 5\% dan glukosa sebanyak 5\%. Kemudian dilakukan pemanasan pada suhu $80^{\circ} \mathrm{C}$ selama 30 menit. Selanjutnya didinginkan sampai suhu $37^{\circ} \mathrm{C}$. Setelah itu diinokulasi dengan kultur starter sebanyak $5 \%$ sesuai taraf perlakuan, yaitu 2 jenis starter pasar (cimory dan king yoghurt) dan 1 starter 
Dwi Eva Nirmagustina dan Chandra Utami Wirawati: Potensi Susu Kedelai Asam (Soygurt) Kaya Bioaktif..

campuran (Lactobacillus bulgaricus : Streptococcus thermopilus). Selanjutnya diinkubasi sesuai taraf perlakuan, yaitu 9 jam, 12 jam, 15 jam. Soygurt yang dihasilkan selanjutnya dilakukan pengujian. Diagram alir pembuatan susu kedelai asam (soygurt) dapat dilihat pada Gambar 3.

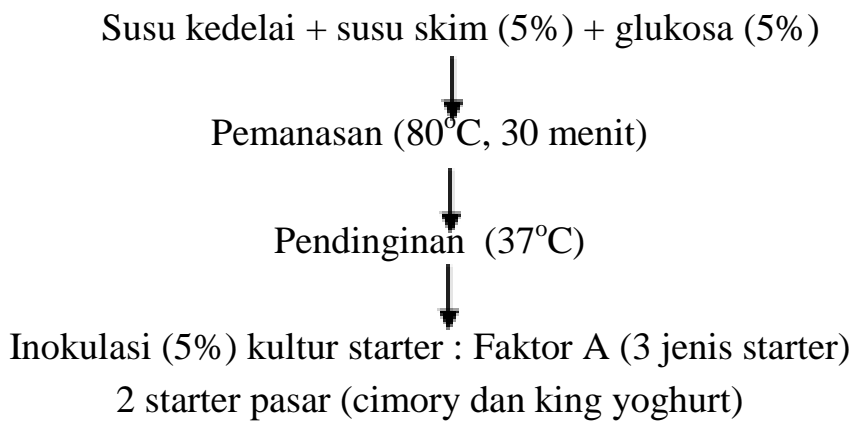

1 starter campuran (Lactobacillus bulgaricus : Streptococcus thermopiles)

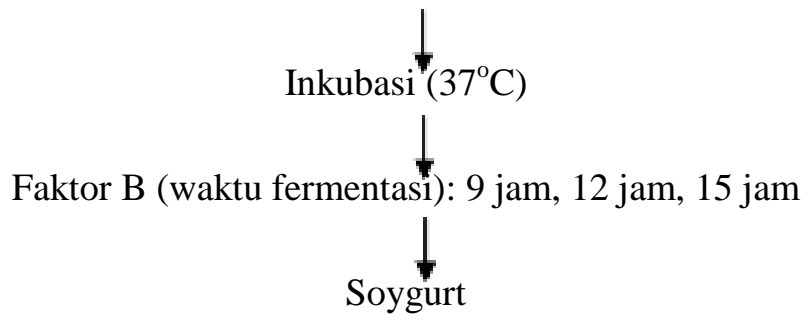

Gambar 2. Diagram alir pembuatan susu kedelai asam (soygurt)

\section{Pengamatan}

Pengamatan yang dilakukan meliputi sifat fisik (total padatan terlarut), sifat kimia ( $\mathrm{pH}$, total asam, protein, lemak), dan sifat fungsional (antimikroba).

A. Sifat fisik

Total padatan terlarut (Apriyantono dkk., 1989)

B. Sifat kimia

a. $\mathrm{pH}$ (Apriyantono dkk., 1989)

b. Total asam Metode titrasi (Apriyantono dkk., 1989)

c. Protein (Penentuan N-Total. Cara Semi Mikro-Kjeldah), Sudarmadji dkk., 1981.

d. Lemak (Penentuan lemak susu cara Babcock), Sudarmadji dkk., 1981.

C. Sifat fungsional (antimikroba)

Sifat fungsional (antimikroba) soyghurt dilakukan dengan uji kontak. Uji kontak adalah metode untuk mengevaluasi daya antimikroba suatu zat dengan cara membandingkan jumlah bakteri uji, sebelum dan sesudah mengalami kontak dengan zat tersebut (Fardiaz 1989).

Tahap awal uji kontak adalah mempersiapkan kultur bakteri uji, yaitu bakteri Escherichia coli dan Staphilococcus aureus umur 24 jam. Kemudian ke dalam soygurt dimasukkan 1\% bakteri E.coli dan S. aureus umur 24 jam dari media Nutrient Broth (NB).

Soygurt yang telah dikontaminasi dengan E. coli dan S. aureus, divorteks untuk menyebarkan sel-sel bakteri. Soygurt tersebut diinkubasikan selama 2 dan 4 jam pada suhu $37^{\circ} \mathrm{C}$. Setelah selesai diinkubasi, dilakukan penghitungan banyaknya sel E.coli dan S. aureus yang bertahan hidup melalui metode hitungan cawan dengan media Nutrien Agar (NA). Selain itu, juga dilakukan penghitungan jumlah sel $E$. coli dan $S$. aureus sebelum dilakukan kontak dengan soygurt melalui metode hitungan cawan dan menggunakan media NA. Selisih jumlah E.coli dan S. aureus 
sebelum dan sesudah kontak menjadi tolok ukur daya antimikroba soyghurt, semakin besar selisihnya maka semakin potensial soygurt tersebut sebagai antimikroba.

Data yang diperoleh dari pengamatan sifat fisik (total padatan terlarut) dan sifat kimia ( $\mathrm{pH}$ dan total asam) dianalisis dengan analisis sidik ragam (Anova) untuk mendapatkan penduga ragam galat dan uji signifikansi dengan uji lanjut Duncan untuk mengetahui ada tidaknya perbedaan antar perlakuan. Sedangkan data yang diperoleh dari pengamatan sifat kimia (protein, dan lemak) dan sifat fungsional (antimikroba) dianalisis secara deskriptif.

\section{HASIL DAN PEMBAHASAN}

Dari hasil pengamatan yang dilakukan terhadap soyghurt yang difermentasi dengan 2 kultur starter pasar (cimory dan king yoghurt) dan 1 kultur starter campuran dengan lama fermentasi 9, 12, dan 15 jam tidak memiliki efek penghambatan oleh senyawa bioaktif peptide. Hal ini diduga mikroba yang terkandung dalam starter pasar cimory (S.thermophilus dan L.delbrueckii ssp. bulgaricus), starter pasar king yoghurt (L.bulgaricus) dan starter campuran (S.thermophilus dan L.bulgaricus.) tidak memproduksi senyawa bioaktif peptide. Meskipun demikian soygurt yang dihasilkan tetap mempunyai sifat antimikroba terhadap bakteri uji E. Coli dan S. aureus yang berasal dari asam laktat dan hydrogen peroksida yang diproduksi selama proses fermentasi.

\section{Sifat Fungsional (Antimikroba)}

Sifat fungsional antimikroba soygurt terhadap bakteri uji E. coli dan S. aureus disajikan pada Gambar 4 dan 5.

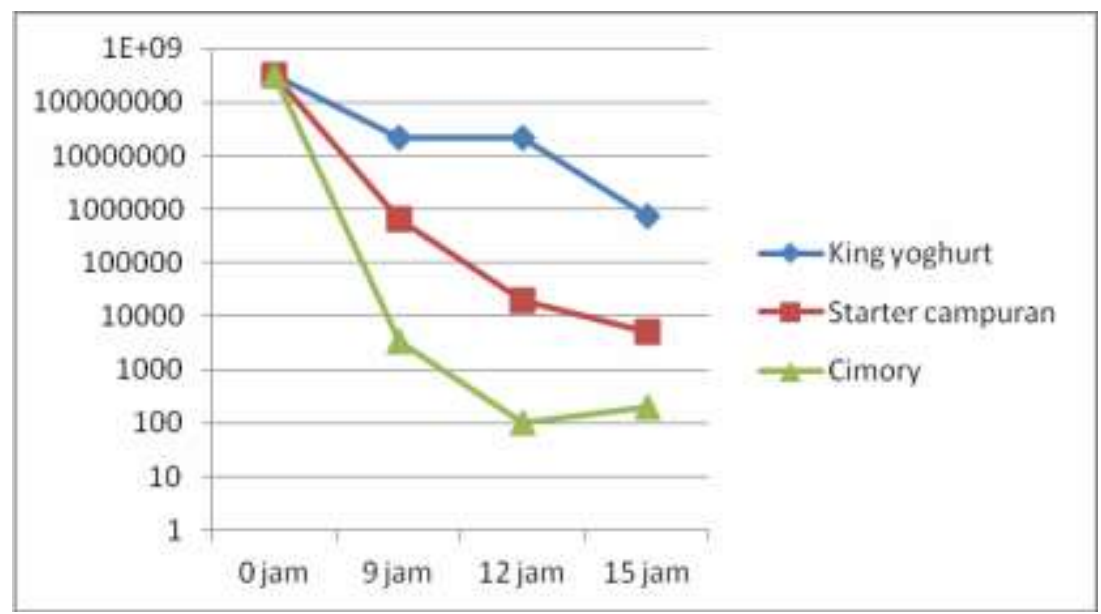

Gambar 4 . Sifat fungsional (antimikroba) soygurt terhadap E. coli

Pada Gambar 4 terlihat bahwa ketiga jenis starter yang digunakan memberikan efek penghambatan terhadap bakteri E. coli dan berbanding lurus dengan lama wartu fermentasi. Semakin lama waktu fermentasi penurunan jumlah sel E.coli juga semakin besar. Penurunan jumlah koloni terbesar ditunjukkan oleh soygurt dengan starter pasar cimory kemudian starter campuran, dan penurunan terendah oleh starter pasar king yoghurt.

Penurunan jumlah koloni E.coli oleh ketiga jenis starter yaitu starter pasar cimory, starter campuran, dan starter pasar king yoghurt berturut-turut adalah sebesar 6 siklus log, 5 siklus log, 
Dwi Eva Nirmagustina dan Chandra Utami Wirawati: Potensi Susu Kedelai Asam (Soygurt) Kaya Bioaktif..

dan 3 siklus log. Jenis spesies yang terkandung di dalam masing-masing starter diduga menghasilkan besar penurunan jumlah E.coli yang berbeda-beda. Starter pasar cimory mengandung 2 jenis kultur bakteri asam laktat yaitu S.thermophilus dan L.delbrueckii ssp. bulgaricus, starter campuran mengandung kultur S.thermophilus dan L.bulgaricus. Sedangkan starter pasar king yoghurt hanya mengandung satu kultur bakteri asam laktat yaitu L.bulgaricus. Tampaknya starter yang terdiri dari 2 kultur campuran bakteri asam laktat akan menghasilkan senyawa antimikroba yang lebih banyak dibandingkan dengan starter dengan kultur tunggal.

Sifat penghambatan yang ditunjukkan oleh ketiga jenis starter diduga disebabkan oleh asam laktat sebagai produk utama selama proses fermentasi. Hal ini sesuai dengan yang dikemukakan oleh Kluyfer dalam Jay (1997) yang menyatakan bahwa bakteri asam laktat homofermentatif merupakan bakteri yang memproduksi asam laktat sebagai produk utama hasil fermentasi glukosa (95\%). Metabolisme glukosa pada bakteri asam laktat homofermentatif terjadi melalui jalur glikolisis (Embden-Meyerhof pathway).

Selain asam senyawa penghambat lainnya diduga adalah hidrogen peroksida. Species Lactobacillus memproduksi hidrogen peroksida dalam jumlah besar melalui piruvat, L-laktat oksidase, D-laktat dehidrogenase, dan NADH oksidase karena species ini tidak memiliki katalase (Dreschel, 1989 dikutip oleh Salminen dan Von Wright, 1993). Hasil pengujian sifat fungsional soygurt terhadap $S$. aures disajikan pada gambar 5 .

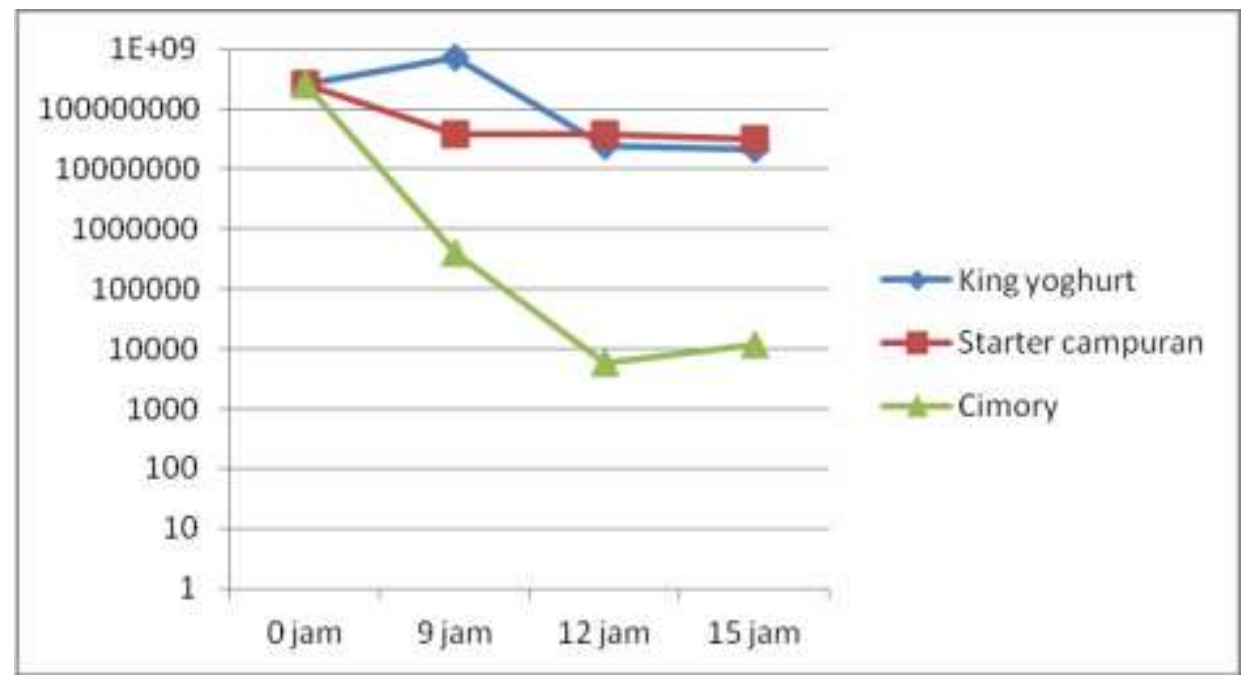

Gambar 5. Pengujian sifat antimikroba soygurt terhadap S. aures

Gambar 5 menunjukkan bahwa penurunan jumlah sel S. aureus terbesar dihasilkan oleh soygurt dari starter pasar cimory yaitu sebesar 4 siklus log. Kemudian diikuti dengan starter campuran dan starter pasar king yoghurt masing-masing sebesar 1 siklus log. Fenomena penghambatan yang terjadi diduga sama dengan penghambatan yang terjadi pada $E$. coli.

\section{Sifat Kimia (pH dan total asam)}

Sifat kimia (pH dan total asam) soygurt disajikan pada Tabel 3 dan 4. Hasil analisis sidik ragam (Anova) menunjukkan bahwa jenis starter dan waku fermentasi berpengaruh nyata terhadap $\mathrm{pH}$ dan total asam soygurt $(\mathrm{P}>0,05)$. 
Tabel 3. Uji lanjut Duncan pH soygurt

\begin{tabular}{clc}
\hline No & \multicolumn{1}{c}{ Kombinasi perlakuan } & Nilai rata-rata \\
\hline 1 & Starter pasar king yoghurt : fermentasi 9 jam & $4,90^{\mathrm{a}}$ \\
2 & Starter pasar king yoghurt : fermentasi 12 jam & $4,93^{\mathrm{a}}$ \\
3 & Starter pasar king yoghurt : fermentasi $15 \mathrm{jam}$ & $4,90^{\mathrm{a}}$ \\
4 & Starter pasar king yoghurt : fermentasi 15 jam & $4,13^{\mathrm{b}}$ \\
5 & Starter campuran: fermentasi 12 jam & $4,13^{\mathrm{b}}$ \\
6 & Starter campuran : fermentasi 15 jam & $4,05^{\mathrm{b}}$ \\
7 & Starter pasar cimory: fermentasi 9 jam & $4,60^{\mathrm{c}}$ \\
8 & Starter pasar cimory: fermentasi 12 jam & $4,42^{\mathrm{d}}$ \\
9 & Starter pasar cimory: fermentasi 15 jam & $4,33^{\mathrm{e}}$ \\
\hline
\end{tabular}

Hasil uji lanjut Duncan (Tabel 3) menunjukkan bahwa starter yang berbeda (starter pasar king yoghurt, starter campuran, dan starter pasar cimory) dengan waktu fermentasi (9, 12, dan 15 jam) menghasilkan $\mathrm{pH}$ soygurt yang berbeda.

Tabel 4. Uji lanjut Duncan total asam soygurt

\begin{tabular}{clc}
\hline No & \multicolumn{1}{c}{ Kombinasi perlakuan } & Nilai rata-rata \\
\hline 1 & Starter pasar king yoghurt : fermentasi 9 jam & $43^{\mathrm{a}}$ \\
2 & Starter pasar king yoghurt : fermentasi 12 jam & $37^{\mathrm{b}}$ \\
3 & Starter pasar king yoghurt : fermentasi 15 jam & $31^{\mathrm{c}}$ \\
4 & Starter pasar king yoghurt : fermentasi 15 jam & $65^{\mathrm{d}}$ \\
5 & Starter campuran: fermentasi 12 jam & $54^{\mathrm{e}}$ \\
6 & Starter campuran : fermentasi 15 jam & $54^{\mathrm{e}}$ \\
7 & Starter pasar cimory: fermentasi 9 jam & $48^{\mathrm{a}}$ \\
8 & Starter pasar cimory: fermentasi 12 jam & $47^{\mathrm{a}}$ \\
9 & Starter pasar cimory: fermentasi 15 jam & $46^{\mathrm{a}}$ \\
\hline
\end{tabular}

Hasil uji lanjut Duncan (Tabel 4) menunjukkan bahwa starter yang berbeda (starter pasar king yoghurt, starter campuran, dan starter pasar cimory) dengan waktu fermentasi (9, 12, dan 15 jam) menghasilkan total asam soyghurt yang berbeda.

Starter campuran memiliki $\mathrm{pH}$ yang paling rendah dan total asam yang paling tinggi dibanding starter pasar cimory dan starter pasar king yoghurt. Hal ini diduga kultur S.thermopillus dan L.bulgaricus yang merupakan bakteri utama yang ada pada starter campuran lebih banyak memproduksi asam laktat sebagai salah satu senyawa antimikroba selama pertumbuhannya. Sementara kedua jenis starter yang lain memproduksi senyawa antimikroba, yang lain selain asam laktat, seperti hidrogen peroksida. Dahiya and Speck (1968) menyatakan bahwa L.brueckii dan L. lactis menghambat pertumbuhan mikroba karena hidrogen peroksida yang dihasilkan.

Diduga penumpukan asam laktat sebagai hasil metabolisme utama pada soygurt akan semakin banyak dengan semakin lamanya waktu fermentasi. Hal serupa juga terjadi pada fermentasi tempoyak yang mengalami penurunan $\mathrm{pH}$ dan peningkatan total asam selama 3 hari waktu fermentasi (Wirawati, 2004).

\section{Sifat Fisik (total padatan terlarut)}

Sifat fisik (total padatan terlarut) disajikan pada Tabel 5. Hasil analisis ragam (Anova) menunjukkan bahwa jenis starter dan waku fermentasi tidak berpengaruh nyata terhadap total padatan terlarut soygurt $(\mathrm{P}<0,05)$. 
Dwi Eva Nirmagustina dan Chandra Utami Wirawati: Potensi Susu Kedelai Asam (Soygurt) Kaya Bioaktif..

Tabel 5. Nilai rata-rata total padatan terlarut (\%) soygurt

\begin{tabular}{clc}
\hline No & \multicolumn{1}{c}{ Kombinasi perlakuan } & Nilai rata-rata \\
\hline 1 & Starter pasar king yoghurt : fermentasi 9 jam & 12,36 \\
2 & Starter pasar king yoghurt : fermentasi 12 jam & 12,56 \\
3 & Starter pasar king yoghurt : fermentasi 15 jam & 12,54 \\
4 & Starter pasar king yoghurt : fermentasi 15 jam & 12,31 \\
5 & Starter campuran: fermentasi 12 jam & 12,97 \\
6 & Starter campuran : fermentasi 15 jam & 12,72 \\
7 & Starter pasar cimory: fermentasi 9 jam & 12,21 \\
8 & Starter pasar cimory: fermentasi 12 jam & 12,16 \\
9 & Starter pasar cimory: fermentasi 15 jam & 11,67 \\
\hline
\end{tabular}

\section{Sifat kimia (kadar protein dan kadar lemak)}

Sifat kimia (kadar protein dan kadar lemak) soygurt disajikan pada Tabel 6. Kadar protein soygurt dari ketiga jenis starter berturut-turut 1,38\%, 1,48\%, dan 1,68 (starter pasar cimory, starter pasar king yoghurt, dan starter campuran), sedangkan kadar lemak soygurt 1.04\%, 1,28\%, dan $1,58 \%$ (starter pasar cimory, starter campuran, dan starter pasar king yoghurt).

Tabel 6. Kadar protein dan lemak soygurt

\begin{tabular}{cccc}
\hline No & Perlakuan & Kadar Protein (\%) & Kadar Lemak (\%) \\
\hline 1 & Starter pasar king yoghurt : fermentasi 15 jam & 1.48 & 1.58 \\
2 & Starter campuran : fermentasi 15 jam & 1.68 & 1.28 \\
3 & Starter pasar cimory: fermentasi 15 jam & 1.38 & 1.04 \\
\hline
\end{tabular}

\section{KESIMPULAN}

Dua starter pasar (cimory dan king yoghurt) dan 1 starter campuran tidak memproduksi senyawa bioaktif peptide. Soygurt dari 2 starter pasar (cimory dan king yoghurt) dan 1 starter campuran memiliki efektifitas penghambatan terhadap bakteri E. coli dan S. aureus karena produksi asam laktat dan hydrogen peroksida selama proses fermentasi. Penghambatan terbesar ditunjukkan oleh soygurt dari starter pasar cimory dengan penurunan jumlah sel pada kedua jenis bakteri uji (E. coli dan S. aureus) sebesar 6 dan 5 siklus log. Starter campuran memiliki pH yang paling rendah dan total asam yang paling tinggi dibanding starter pasar cimory dan starter pasar king yoghurt. Jenis starter dan waku fermentasi tidak berpengaruh nyata terhadap total padatan terlarut soygurt. Kadar protein soygurt berturut-turut 1,38\%, 1,48\%, dan 1,68 \% (starter pasar cimory, starter pasar king yoghurt, dan starter campuran), sedangkan kadar lemak soygurt $1.04 \%$, $1,28 \%$, dan 1,58\% (starter pasar cimory, starter campuran, dan starter pasar king yoghurt).

\section{SARAN}

Disarankan untuk melakukan pembuatan soygurt dari kultur starter murni atau campuran yang lain yang dapat menghasilkan asam laktat, hydrogen periksoda, dan senyawa bioaktif peptide sehingga dapat menghambat pertumbuhan mikroba secara maksimal. Disarankan untuk melakukan pembuatan soygurt dari starter pasar jenis lain seperti, bioactive, yakult, dan yoghurt. 
Jurnal Penelitian Pertanian Terapan

\section{DAFTAR PUSTAKA}

Apriyantono A, dkk. 1989. Penuntun Praktikum Analisis Pangan. Pusat Antar Universitas IPB. Bogor.

Dahiya, RS and Speck, ML. 1968. Hydrogen peroxide formation by lactobacilli and its effect on Staphylococcus aureus. J. Dairy Sci. 51:1568.

Fardiaz, S. 1989. Uji Sanitasi Dalam Industri Pangan. Petunjuk laboratoriu. PAU Pangan dan Gizi IPB. $278 \mathrm{hlm}$.

Hendriani R, Rostinawati T, Kusuma SAF. 2009. Penelusuran Antibakteri Bakteriosin dari Bakteri Asam Laktat dalam Yoghurt Asal Kabupaten Bandung Barat terhadap Staphylococus aureus dan Escherichi coli. Laporan Akhir LITMUD Unpad.

Jay, JM. 1996. Modern Food Microbiology. Ed. Ke-5. New York, Chapman and Hall.

Korhonen H dan Pihlanto A. 2006. Riview: Bioactive Peptides: Production and Functionality. International Dairy Journal 16: 945 - 960.

Marshall SH. 2003. Antimicrobial Peptides: As Natural Al ternative to Chemical Antibiotics And a Potential for Applied Biotechnology. Electron. J. Biotech., $3: 6$.

Salminen dan Von Wright, 1993. Lactic acid bacteria. Marcel Dekker Inc. New York. 442 hlm.

Sari NK. 2007. Pengembangan Produk Minuman Fermentasi Susu Kedelai (Soygurt) dengan Penambahan Ekstrak Teh Hijau (Camelia sinensis) di PT. FajarTaurus Jakarta Timur [Sktipsi]. Institut Pertanian Bogor, Fakultas Teknologi Pertanian.

Shah NP. 1999. Probiotic Bacteria: Selective Enumeration and Survival in Dairy Foods. J. Dairy Sci., 83 : 894-907.

Sudarmadji S, Haryono B, Suhardi. 1988. Prosedur Analisa untuk Bahan Makanan dan Pertanian. Liberty. Yogyakarta.

Yeaman MR, Yount NY. 2003. Perspectives in Antimicrobial Peptide Mechanism of Action and Resistance, Pharmacol. Rev., $55: 27$ - 55.

Wirawati. 2004. Skrining Bakteri Asam laktat dari Tempoyak Sebagai kandidat Probiotik. Jurnal Teknologi dan Industri Hasil Pertanian ISSN 1410-3004 Vol. 8 No 1 Maret 2004. 